\title{
SCHEDULING IN CELLULAR MANUFACTURING SYSTEMS
}

\section{Venkata Chalapathi Pasupuleti*}

ABSTRACT: Once the cellular manufacturing system is designed, scheduling of jobs is essential for the day-to-day production in the machine cells. Scheduling in cellular manufacturing system is generally complicated. In this paper, a methodology has been proposed for prioritizing the parts, as well as preparing the total schedules in a cellular manufacturing system. It takes into account, the processing sequences of the jobs, processing and setup times and due dates. The method works out for different dispatching rules viz., first come first serve, shortest processing time, longest processing time, earliest due date and least slack. Various performance measures like the makespan, mean flow time, mean lateness and mean tardiness are used to evaluate the considered dispatching rules. The method gives the sequence of parts to process on each machine and the total schedules for all the operations of the parts. One numerical example is illustrated for the method and also compared with a bench mark problem.

Keywords: Cellular manufacturing. Scheduling. Sequencing rules. Performance measures.

\section{INTRODUCTION}

Cellular manufacturing is a production system in which the parts requiring similar production process are grouped in distinct manufacturing cells. The benefits of cellular manufacturing system are: reducing the number of setups and material handling costs, decreasing work in process inventories, improving space utilization, better quality and simplified production planning and control (WEMMERLOV; HYER, 1989). CMS also provides a production infrastructure that facilitates successful implementation of modern manufacturing technologies such as just-in-time manufacturing, flexible manufacturing systems, computer integrated manufacturing, etc.

\footnotetext{
${ }^{*}$ Professor and Head of Industrial and Production Engineering Dept., K.L.University, Vijayawada, AP, India, pvenkatachalapathi@yahoo.co.in
}

Iberoamerican Journal of Industrial Engineering, Florianópolis, SC, Brasil, v. 4, n. 7, p. 231-243, 2012. 
There are many issues in the scheduling in CMS (WEMMERLOV; VAKHARIA, 1991). One of the most important issues to attain the benefits of CMS is effective implementation of its scheduling systems. In the literature, scheduling in CMS is addressed as a flow shop group scheduling, where each part family can be processed in one cell by duplicating bottleneck machines or subcontracting exceptional parts, which are not practical. In a typical CMS environment, it is difficult to form independent manufacturing cells and mostly there are some exceptional parts that create inter-cellular moves. These constraints limit the applicability of group scheduling methods in reality. Some heuristics: SVS-algorithm (SOLIMANPUR et al., 2004), CDS method (CAMPBELL et al., 1970), NEH method (NAWAZ et al., 1983) are available in the literature for scheduling in CMS, allowing intercell movements of parts.

SVS-algorithm is a two-stage heuristic for scheduling of manufacturing cells, with intracell scheduling and inter-cell scheduling. Through intra-cell scheduling, the sequence of parts within manufacturing cells is determined. In inter-cell scheduling however, the sequence of cells is obtained. But its disadvantage is that no backtracking in the sequence of machines is allowed. Once a part is completed on a machine, either it continues processing in the same cell or leaves that cell and joins another cell.

Tavakkoli-Moghaddam et al. (2008), presented a group scheduling problem for manufacturing cells, in which parts may visit different cells. By addressing intra-cell scheduling, the sequence of parts within manufacturing cells and in inter-cell scheduling, the sequence of cells are determined. There has been some research, studied the group scheduling problems viz., Allison (1990); Logendran and Nudtasomboon (1991); McRoberts and Vaithiannathan (1981); Taylor and Ham (1981); Vakharia and Chang (1990). Again, all these studies attempted to solve the group scheduling problem by assuming that part families have been pre-established. Several heuristic algorithms for scheduling jobs in GT production systems, found in the literature, had one or more of the following assumptions:

- Similar sequence of operations for all parts in a family and no backtracking of parts

- No duplication of machines in cells

- Production in each cell is treated as a flow shop

Iberoamerican Journal of Industrial Engineering, Florianópolis, SC, Brasil, v. 4, n. 7, p. 231-243, 2012. 
The above assumptions are impractical and a methodology is in fact needed which can take into account of all practical issues.

\section{NOMENCLATURE}

The following sections summarize the notation definitions of these methods.

$\mathrm{N}$ - Number of jobs

$\mathrm{M}$ - Number of machine-types

$\mathrm{OPR}_{\mathrm{i}}-$ Number of operations for job-i, $\quad \mathrm{i}=1,2, \ldots \ldots \ldots, \mathrm{N}$

$\mathrm{SEQ}_{\mathrm{ij}}$ - j-th operation for job-i, $\quad \mathrm{i}=1,2, \ldots \ldots \ldots, \mathrm{N}, \quad \mathrm{j}=1,2, \ldots \ldots \mathrm{OPR}_{\mathrm{i}}$

$\mathrm{PT}_{\mathrm{ij}}$ - Processing time for $\mathrm{j}$-th operation of job-i, $\mathrm{i}=1,2, \ldots \ldots \ldots, \mathrm{N}, \mathrm{j}=1,2, \ldots \ldots \mathrm{OPR}_{\mathrm{i}}$

$\mathrm{DD}_{\mathrm{i}}$ - Due date of job-i, $\quad \mathrm{i}=1,2, \ldots \ldots \ldots, \mathrm{N}$

QTM $_{j}-$ Number of machines of type-j, $\quad j=1,2, \ldots \ldots \ldots, M$

$\mathrm{TT}_{\mathrm{i}}$ - Total processing time of job-i, $\quad \mathrm{i}=1,2, \ldots \ldots \ldots, \mathrm{N}$

$\mathrm{SL}_{\mathrm{i}}$ - Slack time of job-i, $\quad \mathrm{i}=1,2, \ldots \ldots \ldots, \mathrm{N}$

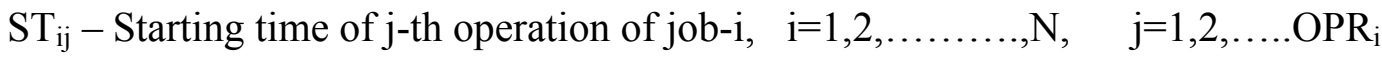

$\mathrm{CT}_{\mathrm{ij}}$ - Closing time of $\mathrm{j}$-th operation of job-i, $\mathrm{i}=1,2, \ldots \ldots \ldots, \mathrm{N}, \quad \mathrm{j}=1,2, \ldots \ldots \mathrm{OPR}_{\mathrm{i}}$

T - Timer

MS - Makespan

MFT - Mean flow time

MLT - Mean lateness

MTD - Mean tardiness

\section{CONCEPTS}

In this paper, a methodology has been proposed for prioritizing the parts as well as preparing schedules, which works without the above mentioned constraints. The special features of the proposed method are:

- Each machine-type is given a unique code in the entire cellular manufacturing.

Iberoamerican Journal of Industrial Engineering, Florianópolis, SC, Brasil, v. 4, n. 7, p. 231-243, 2012. 
- A machine-type in a cell will be given a code and similar machine-type available in other cells will be given different codes. While scheduling, similar machine-types in various cells are treated as if they are different machine-types.

- Duplicate machines are allowed for a machine-type. Based on the production requirement and availability, more number of machines of same type can be placed in a cell.

- If jobs are waiting for production on a particular machine-type, if that machine-type has duplicate machines, simultaneous production of jobs on all duplicate machines is allowed.

- The entire cellular manufacturing system is treated as one job shop production system.

- As the entire cellular manufacturing system is treated as one unit, no distinction is made between inter-cell and intra-cell production. Hence, inter cell operations ie, parts visiting other cells for one or few operations can be carried out simultaneously along with the other parts in that visited cell.

- There are no restrictions regarding backtracking of parts in a cell or among cells. Parts can travel in any direction in their cell or among other cells.

- Parts in each family can have distinct sequence of operations on the machines of the cell. Hence, each cell can be either treated as a job-shop production system.

- The setup time and transportation time are independent of the sequence and are included in the process time of the jobs.

When scheduling in CMS, all the cells in CMS are treated as one system, 2-stage scheduling ie., intra-cell scheduling and inter-cell scheduling are done simultaneously. Production runs in each cell parallel and separately, but the exceptional parts (inter-cell moves) will visit the required cells and join the buffers of respective machines for production. As each machine-type is given a unique code, there will not be any mix up of machines even if similar machine-types are available in other cells.

The problem can be stated as follows: there are $\mathrm{N}$ jobs and $\mathrm{M}$ machine-types, which are grouped into part-families and corresponding machine-cells. All or most of the jobs are processed within that cell or one or fewer jobs may visit other cells for one or fewer

Iberoamerican Journal of Industrial Engineering, Florianópolis, SC, Brasil, v. 4, n. 7, p. 231-243, 2012. 
operations. Each job follows a predefined machining order and has a specified processing time; however the machine order is random from job to job.

The methodology takes input of: number of jobs $N$, number of machine-types $M$, number of operations for each job $\mathrm{OPR}_{\mathrm{i}}$, sequence of operations $\mathrm{SEQ}_{\mathrm{ij}}$, processing times $\mathrm{PT}_{\mathrm{ij}}$, due dates $\mathrm{DD}_{\mathrm{i}}$, number of machines for each type $\mathrm{QTM}_{\mathrm{j}}$.

Total processing times and slack times for all the jobs are calculated. Total processing time for job-i is calculated as, $\mathrm{TTi}=\sum$ PTij where $\mathrm{j}=1,2, \ldots . . \mathrm{OPR}_{\mathrm{i}}$ and slack time as, $\mathrm{SLi}=(\mathrm{DDi}-\mathrm{TTi})$. Setup and transportation times are included into processing times here.

The method works out detailed schedules and corresponding performance measures for each of the five dispatching rules, viz., First Come First Serve, Shortest Processing Time, Longest Processing Time, Earliest Due Date, and Least Slack. After selecting one of the dispatching rules, the timer-T starts from zero. Initial buffers are formed for the machines, based on sequence of operations of jobs. All jobs are dropped into the queues of corresponding machines. In those buffers where there is more than one job waiting for production, the jobs are sequenced within the buffer based on the selected dispatching rule. If more than one machine is available for any machine-type, then the buffer jobs are assigned and adjusted within the number of duplicated machines. The production is started, starting time - $\mathrm{ST}_{\mathrm{ij}}$ and closing time - $\mathrm{CT}$ ij are noted for each job and each operation. T-timer is updated simultaneously every time. Whenever an operation for a job is completed, remaining sequence of operations - $\mathrm{SOP}_{\mathrm{ij}}$ and remaining processing times - $\mathrm{PT}_{\mathrm{ij}}$ are updated for all the jobs. All the buffers are once again updated and jobs are prioritized as per the selected dispatching rule. In the same way, the production is continued and all the parameters are updated till all the operations of jobs are completed. Four performance measures are calculated viz., Make Span, Mean Flow Time, Mean Lateness and Mean Tardiness.

Once the production is completed for a selected dispatching rule, the detailed schedules for each job and corresponding performance measures are printed. The same procedure is repeated for all the dispatching rules. The performance measures can help in evaluating the considered dispatching rules for the given problem.

\section{METHODOLOGY}

Iberoamerican Journal of Industrial Engineering, Florianópolis, SC, Brasil, v. 4, n. 7, p. 231-243, 2012. 
Figure 1.

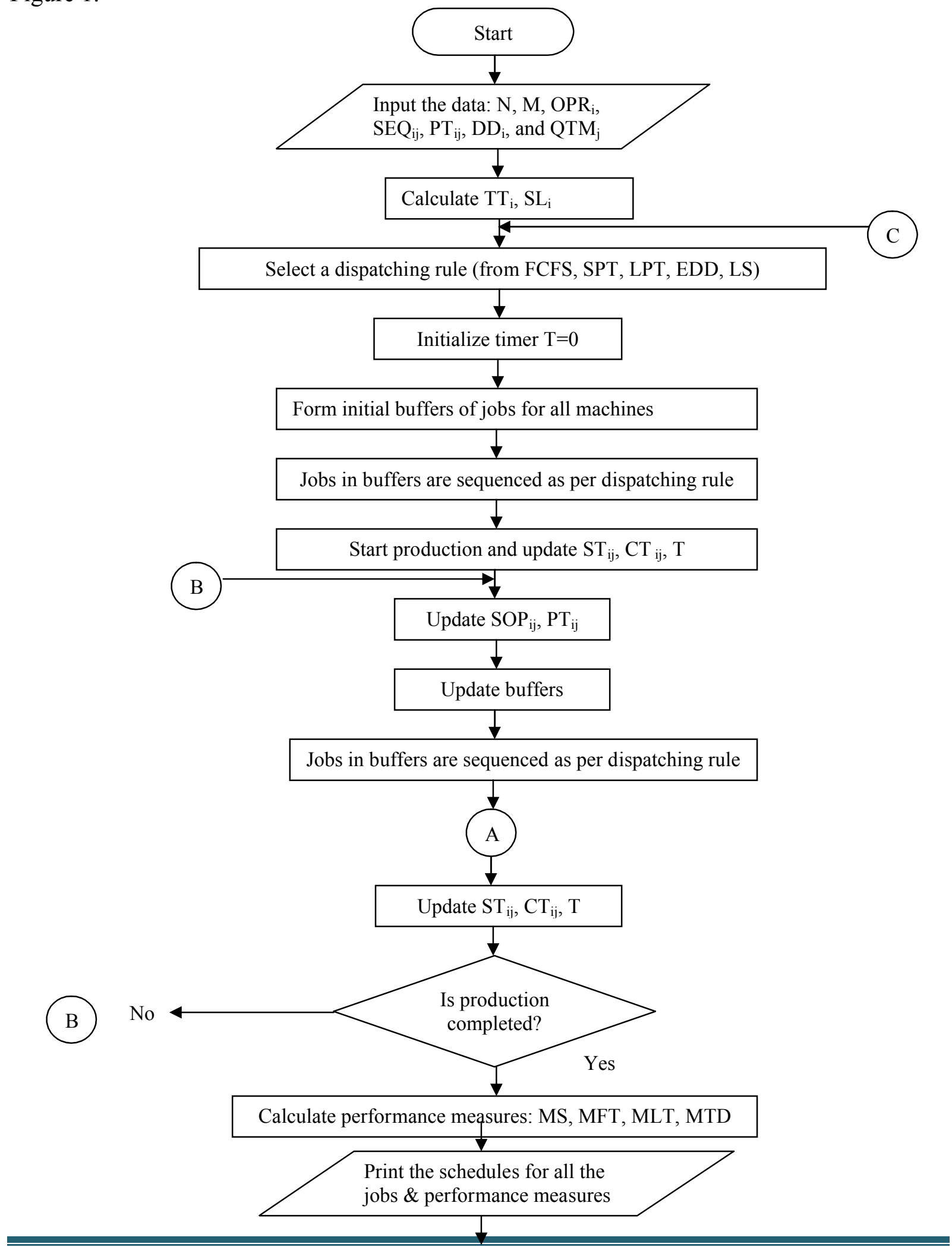

Iberoamerican Journal of Industrial Engineering, Florianópolis, SC, Brasil, v. 4, n. 7, p. 231-243, 2012. 


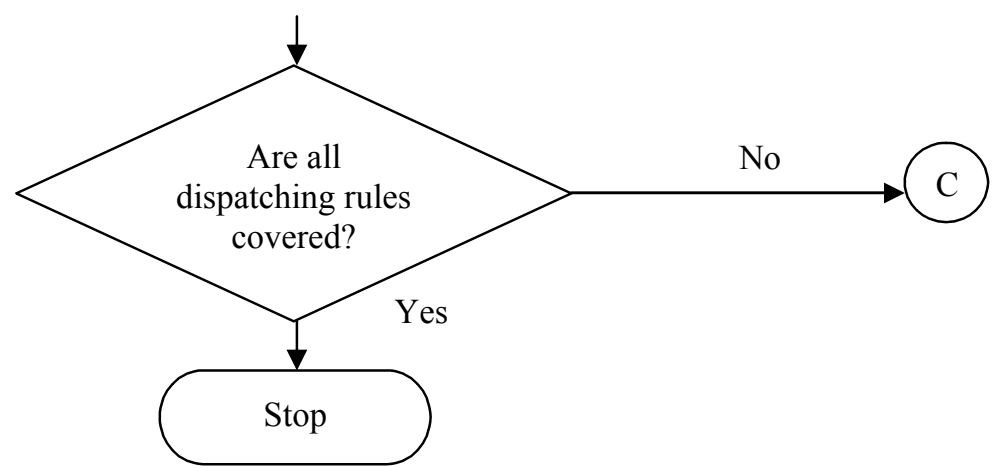

Figure 1 - Flow chart of the methodology

In this paper, a methodology has been proposed for prioritizing the parts as well as preparing schedules.

\section{ILLUSTRATION}

Consider the following cellular manufacturing system with 11 jobs, grouped into 3 families and their associated machines into 3 cells as shown in Figure 2. It has 1 exceptional part/ intercellular movement. The elements in the following matrix indicate the sequence of operation.

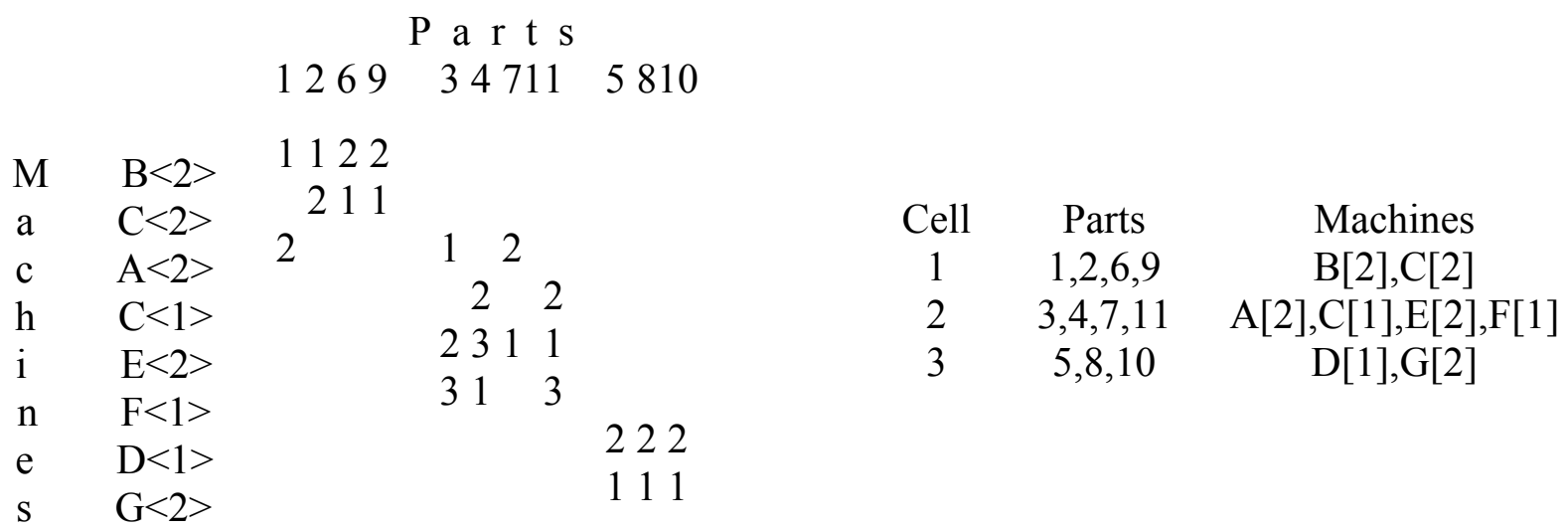

Figure 1 - Elements the matrix

Here duplicate machines are also available (for example: $\mathrm{B}<2>$ indicates machine-type $\mathrm{B}$ with 2 machines). The machine-types are given 1 to 8 code numbers respectively for $\mathrm{B}, \mathrm{C}$, A, C, E, F, D, G in the operation sequence column. The operation sequences (Table 1), processing times and due dates of 11 jobs.

Iberoamerican Journal of Industrial Engineering, Florianópolis, SC, Brasil, v. 4, n. 7, p. 231-243, 2012. 
Table 1 -Operation sequences

\begin{tabular}{l|lllll}
\hline Job No. & Oper. Seq. & Proc. Times & Total time & Due date & Slack \\
\hline 1 & $1-3$ & $4-3$ & 7 & 20 & 13 \\
2 & $1-2$ & $6-5$ & 11 & 20 & 9 \\
3 & $3-5-6$ & $2-3-4$ & 9 & 20 & 11 \\
4 & $6-4-5$ & $1-3-2$ & 6 & 20 & 14 \\
5 & $8-7$ & $8-3$ & 11 & 20 & 9 \\
6 & $2-1$ & $8-5$ & 13 & 20 & 7 \\
7 & $5-3$ & $6-6$ & 12 & 20 & 8 \\
8 & $8-7$ & $3-2$ & 5 & 20 & 15 \\
9 & $2-1$ & $7-3$ & 10 & 20 & 10 \\
10 & $8-7$ & $4-2$ & 6 & 20 & 14 \\
\hline $\mathbf{1 1}$ & $5-4-6$ & $7-4-3$ & 14 & 20 & 6 \\
\hline
\end{tabular}

a) According to FCFS dispatching rule:

Buffer jobs status at various times is given below (it shows the allocation of jobs to various machines in each cell) (Table 2).

Table 2 - Allocation of jobs to various machines in each cell

\begin{tabular}{|c|c|c|c|c|c|c|c|c|c|c|c|c|c|c|c|}
\hline $\mathrm{M} / \mathrm{c}$ & $\mathbf{T}=\mathbf{0}$ & 1 & 2 & 3 & 4 & 5 & 6 & 7 & 8 & 9 & 10 & 11 & 12 & 13 & 16 \\
\hline B & 1 & 1 & 1 & 1 & & & & 9 & 9 & 9 & & & & & \\
\hline B & 2 & 2 & 2 & 2 & 2 & 2 & & & 6 & 6 & 6 & 6 & 6 & & \\
\hline $\mathrm{C}$ & 6 & 6 & 6 & 6 & 6 & 6 & 6,2 & 6 & & & & & & & \\
\hline $\mathrm{C}$ & 9 & 9 & 9 & 9 & 9 & 9 & 9 & 2 & 2 & 2 & 2 & 2 & & & \\
\hline A & 3 & 3 & & & 1 & 1 & 1 & & & & & & & & \\
\hline A & & & & & & & 7 & 7 & 7 & 7 & 7 & 7 & & & \\
\hline $\mathrm{C}$ & & 4 & 4 & 4 & & & & 11 & 11 & 11 & 11 & & & & \\
\hline $\mathrm{E}$ & 7 & 7 & 7,3 & 7,3 & $7,3,4$ & $7,3,4$ & 3,4 & 3 & 3 & & & & & & \\
\hline $\mathrm{E}$ & 11 & 11 & 11 & 11 & 11 & 11 & 11 & 4 & 4 & & & & & & \\
\hline $\mathrm{F}$ & 4 & & & & & & & & & 3 & 3 & 3,11 & 3,11 & 11 & \\
\hline D & & & & 8 & 8 & & & 10 & 10,5 & 5 & 5 & 5 & & & \\
\hline $\mathrm{G}$ & 5,10 & 5,10 & 5,10 & 5 & 5 & 5 & 5 & 5 & & & & & & & \\
\hline $\mathbf{G}$ & 8 & 8 & 8 & 10 & 10 & 10 & 10 & & & & & & & & \\
\hline
\end{tabular}

The detailed schedules of each job and each operation for FCFS rule are (Figure 3):

Iberoamerican Journal of Industrial Engineering, Florianópolis, SC, Brasil, v. 4, n. 7, p. 231-243, 2012. 


\begin{tabular}{|c|}
\hline 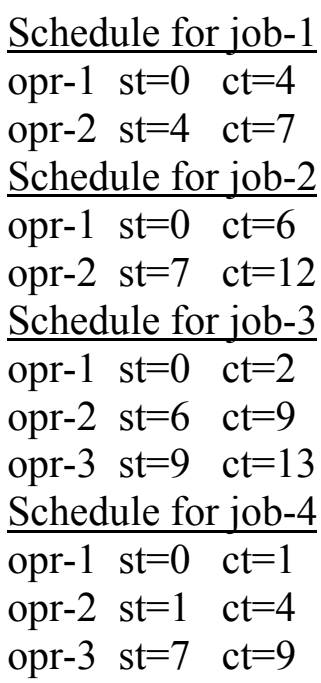 \\
\hline
\end{tabular}

\begin{tabular}{|c|}
\hline$\underline{\text { Schedule for job-5 }}$ \\
\hline opr $-1 \quad \mathrm{st}=0 \quad \mathrm{ct}=8$ \\
\hline opr-2 $\quad \mathrm{st}=9 \quad \mathrm{ct}=12$ \\
\hline Schedule for job- 6 \\
\hline opr $-1 \quad \mathrm{st}=0 \quad \mathrm{ct}=8$ \\
\hline opr $-2 \quad \mathrm{st}=8 \quad \mathrm{ct}=13$ \\
\hline Schedule for job- 7 \\
\hline opr-1 $\quad \mathrm{st}=0 \quad \mathrm{ct}=6$ \\
\hline opr-2 $\mathrm{st}=6 \quad \mathrm{ct}=12$ \\
\hline Schedule for job- 8 \\
\hline opr-1 $\quad \mathrm{st}=0 \quad \mathrm{ct}=3$ \\
\hline opr-2 $\mathrm{st}=3 \quad \mathrm{ct}=5$ \\
\hline
\end{tabular}

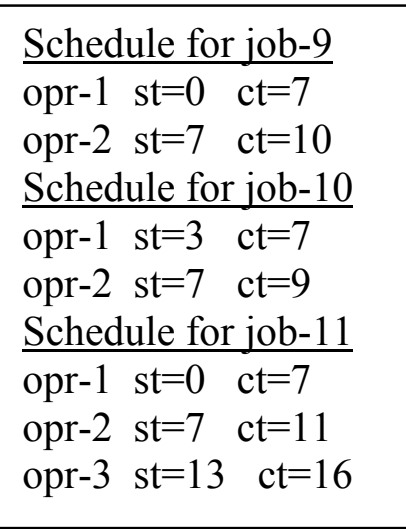

Figure 2 - Detailed schedules of each job and each operation

The performance measures for FCFS rule are:

MAKE SPAN=16

MEAN FLOW TIME $=10.45$

MEAN LATENESS $=-9.27$

MEAN TARDINESS $=0.00$

The same procedure is repeated for other dispatching rules. Due to space limitation the detailed schedules and the performance measures for other dispatching rules are not shown here. User has the liberty to choose the required schedule as per the desired performance measures.

\section{COMPARISON WITH BENCHMARK PROBLEM}

The methodology was applied to a benchmark problem and found that the method outperforms the existing method. An illustrative cell scheduling problem given in Solimanpur et al. (2004), solved using a heuristic that minimize makespan, has been considered here. In this journal, it was solved by SVS-algorithm and mentioned that it was superior to LN-PT method available in the literature. The operation sequence matrix and set-processing time matrix for 10 parts and 8 machines are given in Table 3 and Table 4.

Iberoamerican Journal of Industrial Engineering, Florianópolis, SC, Brasil, v. 4, n. 7, p. 231-243, 2012. 
Table 3 - Operations sequence matrix

\begin{tabular}{|c|c|c|c|c|c|c|c|c|c|c|c|}
\hline & & \multicolumn{10}{|c|}{ Parts } \\
\hline \multirow{9}{*}{$\begin{array}{l}\stackrel{\mathscr{E}}{\Xi} \\
\stackrel{\Xi}{\Xi} \\
\sum_{\Sigma}^{\mathbb{E}}\end{array}$} & & 5 & 6 & 9 & 10 & 1 & 2 & 4 & 3 & 7 & 8 \\
\hline & A & 1 & 1 & 1 & 1 & & & & & & \\
\hline & $\mathrm{D}$ & 3 & 2 & & 2 & & & & & & \\
\hline & $\mathrm{E}$ & 4 & 3 & 2 & & 1 & & & & & \\
\hline & $\mathrm{C}$ & 2 & & & & 2 & 1 & 1 & & 4 & \\
\hline & $\mathrm{G}$ & & & & & 3 & 2 & 2 & & & \\
\hline & B & & & & & & & & 1 & 1 & 1 \\
\hline & $\mathrm{F}$ & 5 & & & & & & & 2 & 2 & 2 \\
\hline & $\mathrm{H}$ & & & & & & & & 3 & 3 & \\
\hline
\end{tabular}

SVS-algorithm solved this problem in 2 stages, viz., intra-cell scheduling and inter-cell scheduling and arrived at a schedule with a minimum makespan of 76.

Table 4 - Set-processing time matrix

\begin{tabular}{|c|c|c|c|c|c|c|c|c|c|c|c|}
\hline & & \multicolumn{10}{|c|}{ Parts } \\
\hline \multirow{9}{*}{ 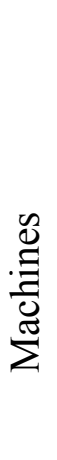 } & & 5 & 6 & 9 & 10 & 1 & 2 & 4 & 3 & 7 & 8 \\
\hline & A & 11 & 8 & 6 & 10 & & & & & & \\
\hline & $\mathrm{D}$ & 16 & 19 & & 7 & & & & & & \\
\hline & $\mathrm{E}$ & 7 & 10 & 13 & & 8 & & & & & \\
\hline & $\mathrm{C}$ & 13 & & & & 6 & 8 & 10 & & 11 & \\
\hline & G & & & & & 16 & 18 & 10 & & & \\
\hline & B & & & & & & & & 5 & 14 & 6 \\
\hline & $\mathrm{F}$ & 5 & & & & & & & 21 & 15 & 13 \\
\hline & $\mathrm{H}$ & & & & & & & & 12 & 7 & \\
\hline
\end{tabular}

The same problem was solved by the proposed methodology, with number of machines of each type as unity and due date of 50 for all the parts. Method gave detailed schedules as per FCFS, SPT, LPT, EDD, LS dispatching rules along with the performance measures MS, MFT, MLT, MTD. Schedules given with minimum MS of 66 are presented in Figure 4.

Iberoamerican Journal of Industrial Engineering, Florianópolis, SC, Brasil, v. 4, n. 7, p. 231-243, 2012. 


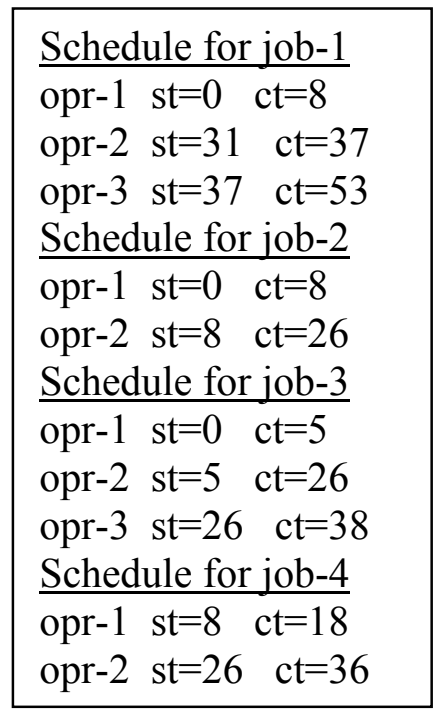

\begin{tabular}{|llll|}
\hline \multicolumn{3}{|c}{ Schedule for job-5 } \\
opr-1 & st $=0$ & ct $=11$ \\
opr-2 & st $=18$ & ct $=31$ \\
opr-3 & st $=38$ & ct $=54$ \\
opr-4 & st $=54$ & ct $=61$ \\
opr-5 & st $=61$ & ct $=66$ \\
Schedule for & job-6 \\
\hline opr-1 & st $=11$ & ct $=19$ \\
opr-2 & st $=19$ & ct $=38$ \\
opr-3 & st $=38$ & ct $=48$ \\
Schedule for & job-7 \\
opr-1 & st $=5$ & ct $=19$ \\
opr-2 & st $=26$ & ct $=41$ \\
opr-3 & st $=41$ & ct $=48$ \\
opr-4 & st $=48$ & ct $=59$
\end{tabular}

Schedule for job-8 opr-1 st=19 ct=25 opr-2 st=41 ct=54 Schedule for job-9 opr-1 st=19 ct=25 opr-2 st $=25$ ct $=38$ Schedule for job-10 opr-1 st $=25$ ct $=35$ opr-2 $\mathrm{st}=54 \quad \mathrm{ct}=61$

Figure 3 - Schedules given by the method with min MS of 66

Referring to Table 5, it can be observed that the proposed methodology has given schedules with minimum makespan of 66 (EDD rule), minimum mean flow time of 43.1 (SPT rule), minimum mean lateness of -6.9 (SPT rule), minimum mean tardiness of 3.9 (FCFS rule).

Table 5 - Performance measures for various dispatching rules

\begin{tabular}{l|rrrr}
\hline & MS & MFT & MLT & MTD \\
\hline FCFS & 73 & 46.9 & -3.0 & 3.9 \\
SPT & 76 & 43.1 & -6.9 & 5.8 \\
LPT & 68 & 50.8 & 0.9 & 5.7 \\
EDD & 66 & 47.9 & -2.0 & 4.4 \\
LS & 68 & 50.8 & 0.9 & 5.7 \\
\hline
\end{tabular}

So, the schedules given by the method are superior to the schedule given by SVS method.

\section{CONCLUSIONS}

In this paper a more practical methodology has been proposed for detailed scheduling of all the jobs in the cellular manufacturing systems, considering the sequence of operations,

Iberoamerican Journal of Industrial Engineering, Florianópolis, SC, Brasil, v. 4, n. 7, p. 231-243, 2012. 
processing times (it can include set-up times also) and due dates for the given cellular manufacturing system (part families and machine cells) along with the number of machines in each machine-type. Method will produce the detailed schedules for each job along with the allocation of jobs for each machine-type in each cell. This procedure is repeated for various dispatching rules viz., FCFS, SPT, LPT, EDD and LS. This algorithm was tested with a variety of numerical data and found that results were satisfactory. One numerical example was illustrated for the method and also compared with a bench mark problem and found that the method is outperforming.

\section{REFERENCES}

ALLISON, J.D. Combining Petrov heuristic and CDS heuristic in group scheduling problems. Computer \& Industrial Engineering, v. 19, n. 1-4, p. 457-461, 1990.

CAMPBELL, H.G; DUDEK, R.A; SMITH, M.L. A heuristic algorithm for $\mathrm{n}$ job, m machine sequencing problem. Management Science, v. 16, n. 10, p. 630-637, 1970.

LOGENDRAN, R; NUDTASOMBOON, N. Minimizing the makespan of a group scheduling problem: A new heuristic. International Journal of Production Economics, v. 22, p. 217230, 1991.

MCROBERTS, K.L; VAITHIANNATHAN, R. A scheduling in a GT environment. Proceedings of the AUTOFACT III Conference, Society of Manufacturing Engineers, 319A-319K, 1981.

NAWAZ, M; ENSCORE, J.E.E; HAM, I. A heuristic algorithm for m-machine, n-job flow shop sequencing problem. International Journal of Management Science, v. 11, n. 1, p. 9195, 1983.

SOLIMANPUR, M; PREM VRAT; RAVI SHANKAR. A heuristic to minimize makespan of cell scheduling problem. International Journal of Production Economics, v. 88, p. 231241, 2004.

TAVAKKOLI-MOGHADDAM, R; GHOLIPOUR-KANANI, Y; CHERAGHALIZADEH, $R$. A genetic algorithm and memetic algorithm to sequencing and scheduling of cellular manufacturing system. International Journal of Management Science and Engineering Management, v. 3, n. 2, p. 119-130, 2008.

TAYLOR, J.F; HAM, I. The use of a micro computer for grouping scheduling. Proceedings of the 9th North American Manufacturing Research Conference (NAMRC), Society of Manufacturing Engineers, v. 636-640, 1981.

Iberoamerican Journal of Industrial Engineering, Florianópolis, SC, Brasil, v. 4, n. 7, p. 231-243, 2012. 
VAKHARIA, A.J; CHANG, Y.L. A simulated annealing approach to scheduling a manufacturing cell. Naval Research Logistics, v. 37, n. 4, p. 559-577, 1990.

WEMMERLOV, U; VAKHARIA, A.J. Job and family scheduling of a flow-line manufacturing cell: A simulation study. IIE Transactions, v. 23, n. 4, p. 383-393, 1993.

WEMMERLOV, U; HYER, N.L. Cellular manufacturing in the US industry. International Journal of Production Research, v. 27, p. 1511-1530, 1989.

Originais recebidos em: $25 / 10 / 2011$

Aceito para publicação em: 16/09/2012

Iberoamerican Journal of Industrial Engineering, Florianópolis, SC, Brasil, v. 4, n. 7, p. 231-243, 2012. 